\title{
Coupling Biocatalysis and Click Chemistry: One-pot Two-step Convergent Synthesis of Enantioenriched 1,2,3-Triazole-Derived Diols
}

\author{
Aníbal Cuetos, ${ }^{a}$ Fabricio R. Bisogno, ${ }^{a, b}$ Iván Lavandera ${ }^{* a}$ and Vicente Gotor ${ }^{* a}$ \\ Received (in $X X X, X X X)$ Xth $X X X X X X X X X 20 X X$, Accepted $X$ th $X X X X X X X X X 20 X X$ \\ ${ }_{5}$ DOI: $10.1039 / b 000000 x$
}

A fully convergent one-pot two-step synthesis of different chiral 1,2,3-triazole-derived diols in high yields and excellent enantio- and diastereoselectivities is shown at very mild conditions in aqueous medium by combining a single alcohol ${ }_{10}$ dehydrogenase (ADH) with a $\mathrm{Cu}$-catalysed 'click' reaction.

Nowadays, the selective synthesis of enantioenriched derivatives for fine chemicals must go in hand with the design of sustainable processes. ${ }^{1}$ Hence, final targets must be obtained with excellent purities, but minimising the use of harmful solvents, reagents and 15 also purification steps involved in a synthetic pathway. ${ }^{2}$ In this sense, the employment of water as reaction medium, ${ }^{3}$ recyclable catalysts ${ }^{4}$ and the design of one-pot multi-step sequential or concurrent synthesis ${ }^{5}$ are highly desired. In the last few years enzymes have been elegantly employed together with organo- or 20 metal-catalyst(s), achieving (chemoenzymatic) one-pot multi-step synthesis of interesting compounds. ${ }^{6}$ Besides lipase-based dynamic processes, ${ }^{7,8}$ most of the examples deal with the concurrent use of oxidoreductases with organo- ${ }^{9}$ or metal- ${ }^{10}$ catalysts. For instance, alcohol dehydrogenases, ${ }^{11}$ responsible of the stereose-

25 lective reduction of carbonylic compounds, have been successfully combined with proline- ${ }^{9 \mathrm{a}}$ or $\mathrm{Zn}$-catalysed ${ }^{10 \mathrm{~b}}$ aldol reactions to obtain enantioenriched 1,3-diols, and with Pd-based catalysts for Wacker-Tsuji, ${ }^{10 a}$ Heck, ${ }^{10 c, j}$ Suzuki, ${ }^{10 d, f, i}$ or Suzuki-Miyaura ${ }^{10 \mathrm{~h}}$ reactions. In these examples, the non-enzymatic transformation 30 occurred first to afford the non-isolated (di)ketone which further underwent $\mathrm{ADH}$-catalysed reduction.

1,2,3-Triazoles are very important pharmacophores that can exert multiple biological activities, ${ }^{12}$ e.g., hydroxylated derivatives have been described as potent $\beta$-adrenergic receptor block35 ers. ${ }^{13 a}$ Besides, triazole-containing structures are versatile ligands in coordination chemistry, ${ }^{13 \mathrm{~b}}$ and some related complexes have displayed antitumor activities. ${ }^{13 c}$ In this sense, the copper(I)catalysed version of the Huisgen cycloaddition in water between an alkyne and an azido compound to form them, is perhaps the 40 most outstanding example of the so-called 'click' chemistry. ${ }^{14} \mathrm{~A}$ $\mathrm{Cu}(\mathrm{I})$ salt must be added into the reaction medium, but in the last few years, the in situ formation of this species by reduction of $\mathrm{Cu}$ (II) salts with, e.g. ascorbate, is mostly employed. Albeit more scarcely studied, comproportionation of a $\mathrm{Cu}(\mathrm{II})$ salt with $\mathrm{Cu}(0)$ 45 is gaining more relevance due to availability and economic issues. ${ }^{15}$ Noteworthy, there are few examples in which biocatalysis and click chemistry have been combined in one-pot procedures, although both protocols can be perfectly compatible. In this sense, it has been reported the kinetic resolution of aromatic 50 epoxides by halohydrin dehalogenase (Hhe)-catalysed azidolysis, affording the corresponding $\beta$-azido alcohols that subsequently reacted with alkynes to achieve chiral 1,2,3-triazole alcohols. ${ }^{16}$ Yields of these processes could be increased by introducing as a first step the bioreduction of an $\alpha$-halo ketone. ${ }^{17}$

55 Herein, we envisaged a one-pot two-step fully convergent strategy in which, starting from two achiral compounds, a pair of suitable chiral precursors could be stereoselectively formed and then assembled by a 'click' reaction, giving rise to a single compound bearing two chiral centres (Scheme 1).

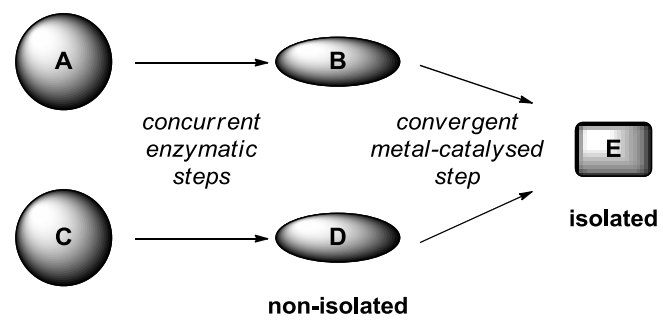

Scheme 1 One-pot two-step fully convergent strategy combining stereoselective enzymatic and metal-catalysed transformations.

The synthesis of the enantioenriched 1,2,3-triazole-derived diols was performed by the concurrent stereoselective bioreduc${ }_{65}$ tion of an $\alpha$-azido- and an alkynyl ketone, followed by cycloaddition catalysed by $\mathrm{Cu}(\mathrm{I})$ in situ formed via comproportionation of $\mathrm{Cu}(\mathrm{II})$ and $\mathrm{Cu}(0)$ (Scheme 2).
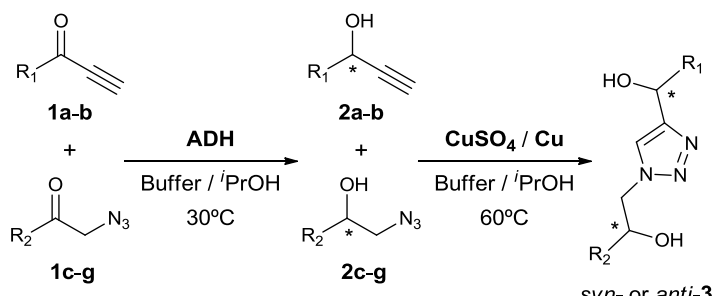

a: $\mathrm{R}_{1}=\mathrm{CH}_{3} ; \mathbf{b}: \mathrm{R}_{1}=\left(\mathrm{CH}_{2}\right)_{4} \mathrm{CH}_{3}$

syn- or anti-3

c: $\mathrm{R}_{2}=\mathrm{Ph} ; \mathbf{d}: \mathrm{R}_{2}=2-\mathrm{Np} ; \mathbf{e}: \mathrm{R}_{2}=\left(\mathrm{CH}_{2}\right)_{5} \mathrm{CH}_{3} ; \mathbf{f}: \mathrm{R}_{2}=4-\mathrm{O}_{2} \mathrm{~N}-\mathrm{Ph} ; \mathbf{g}: \mathrm{R}_{2}=4-\mathrm{HO}-\mathrm{Ph}$

Scheme 2 Chemoenzymatic protocol to synthesise enantioenriched 1,2,370 triazole-derived diols.

Several practical issues were considered in advance: a) both ketones should be quantitatively reduced so, after the cycloaddition step, only diols must be formed, avoiding hydroxy ketones or diketones that would make the purification more complex; b) 
alkynyl ketones may decompose in aqueous media, ${ }^{18}$ so the bioreduction step must be also quick and clean; c) the selectivity of the ADH-catalysed process must be high to avoid the formation of diastereoisomers at the end of the sequence; d) the 5 cycloaddition step must take place in the presence of the enzyme and the hydroalcoholic medium without loss of the performance; and e) it would be highly desirable that the $\mathrm{Cu}(0)$-precatalyst source could be easily recycled with no stirring impairment.

In a first set of experiments, we studied the influence of diffe10 rent alkynones (1a-b) and $\alpha$-azido ketones (1c-g) bearing aliphatic or aromatic (phenyl or 2-naphthyl) groups with, e.g. nitro or hydroxy moieties, on ADH-catalysed reductions using Prelog ADHs overexpressed in E. coli (ADH-A from Rhodococcus ruber, ${ }^{19}$ ADH-T from Thermoanaerobium sp., ${ }^{20}$ and TesADH 15 from Thermoanaerobacter ethanolicus ${ }^{21}$ ) or commercially available anti-Prelog enzymes (LBADH from Lactobacillus brevis ${ }^{22}$ or LKADH from Lactobacillus kefir ${ }^{23}$ ). In ADH-catalysed bioreductions, Tris. $\mathrm{HCl}$ buffer is usually a suitable medium, but it was observed that alkynones were not stable, so we turned to phos20 phate buffer $50 \mathrm{mM} \mathrm{pH} 7.5$ at $30^{\circ} \mathrm{C}$ and $250 \mathrm{rpm}$, in which these derivatives remained stable for longer periods. Under these conditions, the reduction of all ketones was tested using ADHs (Table 1), showing in some cases quantitative conversions $(c)$ and excellent stereoselectivities (ee).

25 Table 1 Stereoselectivities in selected bioreductions of alkynones $\mathbf{1 a - b}$ and $\alpha$-azido ketones 1c-g employing ADHs $(t=24 \mathrm{~h})^{a}$

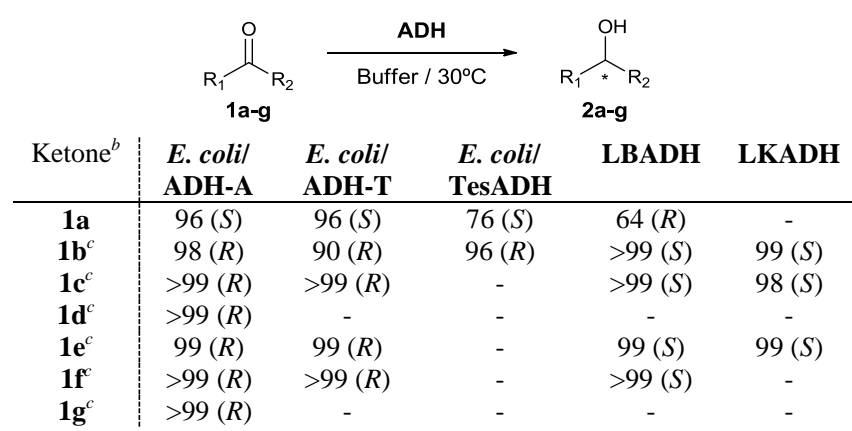

${ }^{a}$ For experimental details, see ESI. ${ }^{b}$ In all cases where $e e$ value appears, the conversion was quantitative. For incomplete reactions, see $c$ and $e e$ in 30 Tables S1 and S2 in ESI. ${ }^{c}$ Change in Cahn-Ingold-Prelog (CIP) priority.

Especially $\mathrm{ADH}-\mathrm{A}$ as Prelog representative enzyme and LBADH as anti-Prelog counterpart rendered quantitative conversions and excellent $e e$ with several substrates. Furthermore, they were able to accept both alkynones and $\alpha$-azido ketones, being 35 excellent candidates to achieve the desired one-pot process. In a second stage, simultaneous bioreduction of a 1:1 mixture of alkynone/azido derivatives was tried to study if any interference could exist, either between reactants or with the ADH. Pleasingly, both substrates were perfectly reduced with the same values of 40 stereoselectivity and no cross-inhibition was detected.

Later, the Cu-catalysed 'click' reaction was studied to find out suitable conditions. With this regard, the source of $\mathrm{Cu}(\mathrm{I})$ was firstly studied using as model substrates racemic alcohols rac-2a and rac-2c to afford a mixture of diols syn- and anti-3ac. ${ }_{45} \mathrm{CuSO}_{4}$ /ascorbic acid in a $\mathrm{H}_{2} \mathrm{O}:{ }^{t} \mathrm{BuOH} 1: 1 \mathrm{v} \mathrm{v}^{-1}$ mixture was tried at room temperature for $24 \mathrm{~h}$, but the conversion was not complete. At this point, we envisaged a system that could be simple, economic and environmentally friendly to obtain $\mathrm{Cu}(\mathrm{I})$ via com- proportionation using $\mathrm{Cu}$ wire with a catalytic amount of $\mathrm{CuSO}_{4}$. ${ }_{50}$ Thus, a copper wire was rolled on a magnetic bar (see ESI), allowing at the same time stirring, an easy recovery and its reuse along several cycles. Different solvent mixtures were tried $\left(\mathrm{H}_{2} \mathrm{O}:{ }^{t} \mathrm{BuOH} 1: 1 \mathrm{v} \mathrm{v}^{-1} ; \mathrm{H}_{2} \mathrm{O}:{ }^{i} \mathrm{PrOH} 1: 1 \mathrm{v} \mathrm{v}^{-1} ; \mathrm{H}_{2} \mathrm{O}:{ }^{i} \operatorname{PrOH} 95: 5 \mathrm{v}\right.$ $\mathrm{v}^{-1}$ ) at $60^{\circ} \mathrm{C}$ for $24 \mathrm{~h}$, obtaining in all cases the triazole diols with 55 quantitative conversions, but since the enzymatic step took place with ${ }^{i} \mathrm{PrOH}\left(5 \% \mathrm{v} \mathrm{v} \mathrm{v}^{-1}\right),{ }^{24}$ we chose the last setting to perform the sequential chemoenzymatic transformation. Microwave heating was also tried, but due to the formation of by-products, e.g. 1,5regioisomers, ${ }^{25}$ this methodology was not further investigated. ${ }_{60}$ After four cycles, the $\mathrm{Cu}$ wire got passivated, but it could be recovered by simple washing with $\mathrm{HCl} 2 \mathrm{~N}$ during $5 \mathrm{~min}$.

In the final stage, the one-pot fully convergent chemoenzymatic approach was achieved furnishing the 1,2,3-triazole-derived diols in good overall yields and excellent selectivities (Figure 1). ${ }_{65}$ After performing the bioreduction in phosphate buffer at $30^{\circ} \mathrm{C}$ with 2-propanol for $24 \mathrm{~h}$, the copper wire and $\mathrm{CuSO}_{4}$ were added into the reaction mixture, and it was heated up at $60^{\circ} \mathrm{C}$ for $24 \mathrm{~h}$. While with alkynone $\mathbf{1 b}$ diols $s y n-\mathbf{3}$ were obtained, in case of substrate 1a, since the enzyme recognised the ethynyl group as 70 the 'big' moiety, ${ }^{26}$ anti-3 were synthesised.
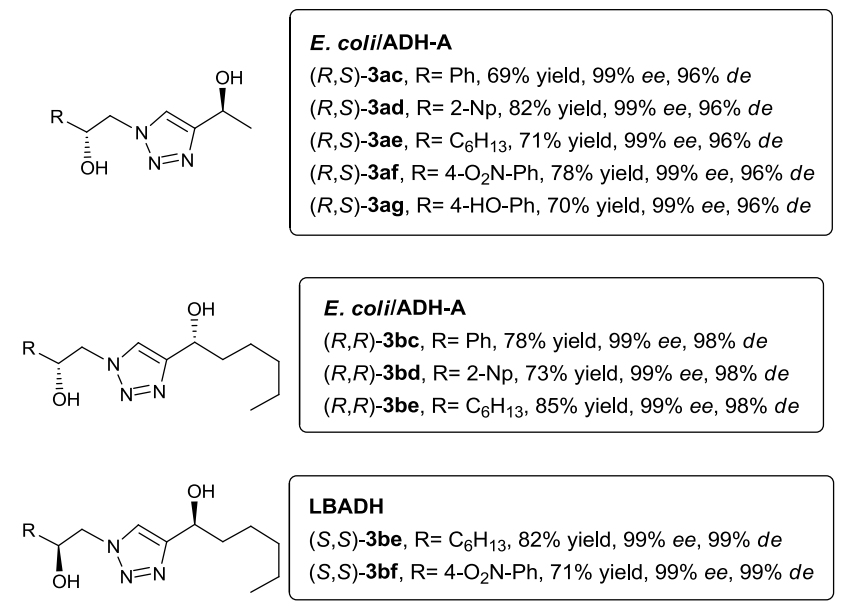

Figure 1 Examples of 1,2,3-triazole-derived diols synthesised using this chemoenzymatic approach. ee values correspond to the major diastereoisomer obtained. Isolated yields (69-85\%) are relative to the diastereoisomeric mixture of the final diols.

\section{Conclusions}

In the last years, the combination of bio- and metal-catalysis has emerged as a potent tool to achieve the synthesis of novel derivatives in a 'one-pot' fashion, thus avoiding the time-consuming 80 and yield-lowering isolation of intermediates. In this sense, biocatalysed redox processes and copper(I)-catalysed [3+2] cycloadditions can be perfectly compatible in an environmentally benign medium like water. Herein it has been developed a onepot two-step fully convergent ${ }^{27}$ synthesis of different chiral 1,2,385 triazole-derived diols in high yields and excellent enantio- and diastereoselectivities at very mild conditions. Hence, starting from two prochiral ketones and using a single ADH with ${ }^{i} \mathrm{PrOH}$ in a first step, and then applying a catalytic amount of $\mathrm{CuSO}_{4}$ and a $\mathrm{Cu}$-wrapped stirring bar, a triazole core bearing two chiral ${ }_{90}$ centres could be easily synthesised. Moreover, the $\mathrm{Cu}(0)$-preca- 
talyst could be recycled, easily removed, and remained active after several cycles. The possibility of the enzymatic recycling via immobilisation ${ }^{28}$ could also afford a more efficient and costeffective method. This system has also the advantage that by 5 simple selection of the enzyme, the chirality of the final compounds can be finely tuned.

A.C. thanks the Principado de Asturias for his predoctoral fellowship Severo Ochoa. I. L. (Ramón y Cajal Program) thanks the Spanish MICINN for personal funding. Financial support 10 from MICINN (Project MICINN-12-CTQ2011-24237) and BIOTRAINS Marie Curie ITN, financed by the European Union through the Seventh Framework People Programme (Grant Agreement no. 238531) are gratefully acknowledged.

\section{Notes and references}

$15{ }^{a}$ Dpto. de Química Orgánica e Inorgánica, Instituto Universitario de Biotecnología de Asturias, Universidad de Oviedo. c/ Julián Clavería 8, 33006, Oviedo (Spain). Fax: +34 985 103448; Tel: +34 985 103452; Email: lavanderaivan@uniovi.es orvgs@uniovi.es.

${ }^{b}$ Current address: INFIQC-CONICET, Dpto. de Química Orgánica,

20 Facultad de Ciencias Químicas, Universidad Nacional de Córdoba,

Ciudad Universitaria, CP 5000, Córdoba (Argentina).

$\dagger$ Electronic Supplementary Information (ESI) available: [experimental procedures, analytics and copies of ${ }^{1} \mathrm{H}$ - and ${ }^{13} \mathrm{C}-\mathrm{NMR}$ of the novel compounds are shown]. See DOI: 10.1039/b000000x/

251 (a) R. Noyori, Nature Chem., 2009, 1, 5; (b) M. Breuer, K. Ditrich, T. Habicher, B. Hauer, M. Keßeler, R. Stürmer and T. Zelinski, Angew. Chem. Int. Ed., 2004, 43, 788.

2 Recent bibliography: (a) R. A. Sheldon, Chem. Soc. Rev., 2012, 41, 1437; (b) P. J. Dunn, Chem. Soc. Rev., 2012, 41, 1452.

303 (a) M.-O. Simon and C.-J. Li, Chem. Soc. Rev., 2012, 41, 1415; (b) R. N. Butler and A. G. Coyne, Chem. Rev., 2010, 110, 6302; (c) A. Chanda and V. V. Fokin, Chem. Rev., 2009, 109, 725.

4 Recent reviews: (a) C. M. Monteiro, A. F. Trindade, P. M. P. Gois and C. A. M. Afonso, in Catalytic Methods in Asymmetric Catalysis, eds. M. Gruttadauria and F. Giacalone, John Wiley \& Sons, Hoboken, 2011, p. 3; (b) M. Gruttadauria, F. Giacalone and R. Noto, in Catalytic Methods in Asymmetric Catalysis, eds. M. Gruttadauria and F. Giacalone, John Wiley \& Sons, Hoboken, 2011, p. 83.

5 See, for instance: (a) E. Ricca, B. Brucher and J. H. Schrittwieser,

$40 \quad$ Adv. Synth. Catal., 2011, 353, 2239; (b) J. H. Schrittwieser, J. Sattler, V. Resch, F. G. Mutti and W. Kroutil, Curr. Opin. Chem. Biol., 2011, 15, 249; (c) F. R. Bisogno, I. Lavandera and V. Gotor, in KirkOthmer Encyclopedia of Chemical Technology, John Wiley \& Sons, Hoboken, 2011, p. 1; (d) Multi-step Enzyme Catalysis, ed. E. GarcíaJunceda, Wiley-VCH, Weinheim, 2008.

6 A. C. Marr and S. Liu, Trends Biotechnol., 2011, 29, 199.

7 (a) I. Hussain and J.-E. Bäckvall, in Enzyme Catalysis in Organic Synthesis, $3^{\text {rd }}$ ed., eds. K. Drauz, H. Gröger and O. May, Wiley-VCH, Weinheim, 2012, p. 1777; (b) H. Pellisier, Adv. Synth. Catal., 2011,

353, 659; (c) Y.-W. Kim, J.-W. Park and M.-J. Kim, ChemCatChem, 2011, 3, 271; (d) N. J. Turner, Curr. Opin. Chem. Biol., 2010, 14, 115; (e) J. Steinreiber, K. Faber and H. Griengl, Chem. Eur. J., 2008, 14,8060 .

8 For other examples involving lipases and metal-catalysts in 'one-pot'

55 processes, see: (a) K. Tenbrink, M. Seßler, J. Schatz and H. Gröger, Adv. Synth. Catal., 2011, 353, 2363; (b) A. Caiazzo, P. M. L. Garcia, R. Wever, J. C. M. van Hest, A. E. Rowan and J. N. H. Reek, Org. Biomol. Chem., 2009, 7, 2926.

9 (a) K. Baer, M. Kraußer, E. Burda, W. Hummel, A. Berkessel and H.

60 Gröger, Angew. Chem. Int. Ed., 2009, 48, 9355; (b) R. Schoevaart and T. Kieboom, Tetrahedron Lett., 2002, 43, 3399.

10 (a) I. Schnapperelle, W. Hummel and H. Gröger, Chem. Eur. J., 2012, 18, 1073; (b) S. Sonoike, T. Itakura, M. Kitamura and S. Aoki, Chem. Asian J., 2012, 7, 64; (c) A. Boffi, S. Cacchi, P. Ceci, R. Cirilli, G. Fabrizi, A. Prastaro, S. Niembro, A. Shafir and A. Vallribera, ChemCatChem, 2011, 3, 347; (d) E. Burda, W. Bauer, W.
Hummel and H. Gröger, ChemCatChem, 2010, 2, 67; (e) F. G. Mutti, A. Orthaber, J. H. Schrittwieser, J. G. de Vries, R. Pietschnig and W. Kroutil, Chem. Commun., 2010, 46, 8046; ( $f$ ) V. Gauchot, W. Kroutil and A. R. Schmitzer, Chem. Eur. J., 2010, 16, 6748; $(g)$ S. Cacchi, R. Cirilli, G. Fabrizi, S. Sgalla, A. Macone, A. Bonamore and A. Boffi, J. Mol. Catal. B: Enzym., 2009, 61, 184; (h) A. Prastaro, P. Ceci, E. Chiancone, A. Boffi, R. Cirilli, M. Colone, G. Fabrizi, A. Stringaro and S. Cacchi, Green Chem., 2009, 11, 1929; (i) E. Burda, W. Hummel and H. Gröger, Angew. Chem. Int. Ed., 2008, 47, 9551; (j) S. Sgalla, G. Fabrizi, R. Cirilli, A. Macone, A. Bonamore, A. Boffi and S. Cacchi, Tetrahedron: Asymmetry, 2007, 18, 2791.

11 Recent bibliography: (a) E. García-Urdiales, I. Alfonso and V. Gotor, Chem. Rev., 2011, 111, PR110; (b) F. Hollmann, I. W. C. E. Arends and D. Holtmann, Green Chem., 2011, 13, 2285; (c) M. M. Musa and R. S. Phillips, Catal. Sci. Technol., 2011, 1, 1311; (d) M. Hall and A. S. Bommarius, Chem. Rev., 2011, 111, 4088; (e) G. W. Huisman, J. Liang and A. Krebber, Curr. Opin. Chem. Biol., 2010, 14, 122.

12 (a) S. G. Agalave, S. R. Maujan and V. S. Pore, Chem. Asian J., 2011, 6, 2696; (b) R. Kharb, P. C. Sharma and M. S. Yar, J. Enzyme Inhib. Med. Chem., 2011, 26, 1; (c) R. S. Bohacek, C. McMartin and W. C. Guida, Med. Res. Rev., 1996, 16, 3.

13 (a) H. Ankati, Y. Yang, D. Zhu, E. R. Biehl and L. Hua, J. Org. Chem., 2008, 73, 6433; (b) W. Yan, X. Ye, N. G. Akhmedov, J. L.

90 Petersen and X. Shi, Org. Lett., 2012, 14, 2358; (c) I. Bratsos, D. Urankar, E. Zangrando, P. Genova-Kalou, J. Košmrlj, E. Alessio and I. Turel, Dalton Trans., 2011, 40, 5188.

14 (a) J. E. Hein and V. V. Fokin, Chem. Soc. Rev., 2010, 39, 1302; (b) M. Meldal and C. W. Tornoe, Chem. Rev., 2008, 108, 2952; (c) M. V. Gil, M. J. Arévalo and O. López, Synthesis, 2007, 1589; (d) J. E. Moses and A. D. Moorhouse, Chem. Soc. Rev., 2007, 36, 1249; (e) V. D. Bock, H. Hiemstra and J. H. Van Maarseveen, Eur. J. Org. Chem., 2006, 51; $(f)$ H. C. Kolb, M. G. Finn and K. B. Sharpless, Angew. Chem. Int. Ed., 2001, 40, 2004.

10015 (a) S. K. Yousuf, S. C. Taneja and D. Mukherjee, J. Org. Chem., 2010, 75, 3097; (b) J. S. Yadav, B. V. S. Reddy, G. M. Reddy and S R. Anjum, Tetrahedron Lett., 2009, 50, 6029; (c) J. Broggi, H. Kumamoto, S. Berteina-Raboin, S. P. Nolan and L. A. Agrofoglio, Eur. J. Org. Chem., 2009, 1880; (d) Q. Wan, J. Chen, G. Chen and S. J. Danishefsky, J. Org. Chem., 2006, 71, 8244; (e) N. Kaval, D. Ermolat'ev, P. Appukkuttan, W. Dehaen, C. O. Kappe and E. Van der Eycken, J. Comb. Chem., 2005, 7, 490; (f) P. Appukkuttan, W. Dehaen, V. V. Fokin and E. Van der Eycken, Org. Lett., 2004, 6, 4223.

11016 L. S. Campbell-Verduyn, W. Szymański, C. P. Postema, R. A. Dierckx, P. H. Elsinga, D. B. Janssen and B. L. Feringa, Chem. Commun., 2010, 46, 898.

17 W. Szymanski, C. P. Postema, C. Tarabiono, F. Berthiol, L. Campbell-Verduyn, S. de Wildeman, J. G. de Vries, B. L. Feringa and D. B. Janssen, Adv. Synth. Catal., 2010, 352, 2111.

18 (a) A. Jakoblinnert, R. Mladenov, A. Paul, F. Sibilla, U. Schwaneberg, M. B. Ansorge-Schumacher and P. Domínguez de María, Chem. Commun., 2011, 47, 12230; (b) C. Heiss and R. S. Phillips, J. Chem. Soc., Perkin. Trans. 1, 2000, 2821.

12019 W. Stampfer, B. Kosjek, C. Moitzi, W. Kroutil and K. Faber, Angew. Chem. Int. Ed., 2002, 41, 1014.

20 J. Peters, T. Minuth and M.-R. Kula, Enzyme Microb. Technol., 1993, 15, 950 .

21 C. Heiss, M. Laivenieks, J. G. Zeikus and R. S. Phillips, Bioorg. Med. Chem., 2001, 9, 1659.

22 M. Wolberg, W. Hummel, C. Wandrey and M. Müller, Angew. Chem. Int. Ed., 2000, 39, 4306.

23 W. Hummel, Appl. Microbiol. Biotechnol., 1990, 34, 15.

24 Except for LKADH, where glucose/GDH was used for cofactor recycling, $5 \% \mathrm{v} \mathrm{v}^{-1}{ }^{i} \mathrm{PrOH}$ was utilised as hydrogen donor.

25 A. Barge, S. Tagliapietra, A. Binello and G. Cravotto, Curr. Org. Chem., 2011, 15, 189.

26 M. Kurina-Sanz, F. R. Bisogno, I. Lavandera, A. A. Orden and V. Gotor, Adv. Synth. Catal., 2009, 351, 1842.

13527 J. B. Hendrickson, J. Am. Chem. Soc., 1977, 99, 5439.

28 (a) U. Hanefeld, L. Gardossi and E. Magner, Chem. Soc. Rev., 2009, 38, 453; (b) R. A. Sheldon, Adv. Synth. Catal., 2007, 349, 1289. 